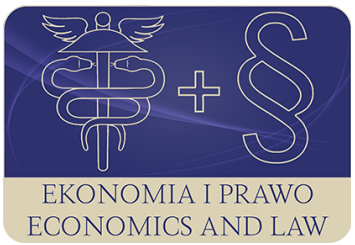

EKONOMIA I PRAWO. ECONOMICS AND LAW

Volume 19, Issue 3, September 2020

p-ISSN 1898-2255, e-ISSN 2392-1625

www.economicsandlaw.pl

EKONOMIA I PRAWO
ECONOMICS AND LAW

ORIGINAL ARTICLE

received 15.03.2020; revised 14.05.2020; accepted 30.09.2020

Citation: Dziawgo, D. (2020). Loyalty program for investors as tool for maintaining relations with shareholders. Ekonomia i Prawo. Economics and Law, 19(3): 479-491.

doi:10.12775/EiP.2020.032.

\title{
Loyalty program for investors as tool for maintaining relations with shareholders
}

\author{
DANUTA DZIAWGO \\ Nicolaus Copernicus University in Torun, Faculty of Economic Sciences and Management, \\ Department of Financial Accounting, ul. Gagarina 13a, 87-100 Toruń, Poland \\ $\square$ ddziawgo@umk.pl \\ orcid.org/0000-0003-0550-3902
}

\begin{abstract}
Motivation: Modern capital market is crucial for maintaining financial stability of economy worldwide. Building and supporting such stability is not possible without bilateral communication between company and investors. One of means of communication between company and investors are loyalty programs that tighten financials link with share-

holder and establish loyal base of clients on the basis of individual investors.

Aim: The subject of this study are loyalty programs dedicated for investors which are alternatively know as benefits programs for investors. The research objective is to identify the need for such programs.

Results: The analysis of the literature as well as international cases of companies' offer investors loyalty programs and also own survey results show that such programs are widely used and are positively assessed by investors. Moreover, loyalty pyramid for investors was formulated and loyalty programs offered on the market were classified. Furthermore, results of the survey analysis from 2020 conducted on 306 Polish individual investors

with the aim of analysing validity of loyalty programs offering were presented.
\end{abstract}

Keywords: individual investors; loyalty program; benefits program; capital market JEL: D14; D91; E21; G41; G51

\section{Introduction}

In modern economy, significance of saving and investing financial resources by households is recognized. Therefore, individual investors on stock exchange market are its' crucial and integral component. Direct investments of individ- 
ual investors have significant importance not only from an economic standpoint (both in micro- and macroeconomy) but also from a social one. Vast social engagement - capital and proprietary - in economic processes is important for every economy.

Considering significance of investments made by individual investors, not only financial aspect is to be analysed. Qualitative aspects concerning impact of such investments on overall functioning of the modern economy and modern society are also essential. Quantitative significance of individual investors investments is indicated by statistical data. It is estimated that on the international stock exchange market, hundreds of billions USD are allocated by individual investors, who own significant overall shares on the overall market. In multiple countries, individual investors constitute for significant share of citizens (Dziawgo, 2004, pp. 95-112).

Simultaneously, several initiatives aiming at encouraging to save and to invest are being undertaken. Among them, as active initiation parties, are (scheme 1): - aiming at education and security of interests of their members' activity of individual investors associations;

- offering by countries special programs encouraging citizens to save and invest, as well as offering tax incentives;

- offering by publicly listed companies special loyalty programs to individual investors, usually in compliance to shareholders' management structure.

The literature on the subject extensively describes investors' rights in respect of their financial instruments, distinguishing property and corporate rights. In the case of shareholders, property rights include the right to dividend, pre-emptive rights to new issues of shares and the right to participate in company asset if bankruptcy occur. In contrast, corporate rights include voting rights at a general meeting of shareholders. A consequence of this right is the right to participate in the general meeting of shareholders, the right to vote when choosing company bodies, the right to appeal against resolutions, the right to acknowledge the activities of the company's management and supervisory bodies, the right to information about the company's financial status. Corporate rights also include the special rights of minority shareholders, which are designed to safeguard the interests of minority shareholders.

Undoubtedly, an important investor right is to obtain financial benefits from investments made (scheme 2). In case of shares, investors benefit from: increased share price, dividend payments and pre-emptive rights granted. However, this approach can now be considered classic. As a result, from changes on the market, the classification should be expanded with an additional element - the benefits from the participation in loyalty programs for shareholders.

This is an additional profit for an investor from holding shares in a given company. For example, it can be a discount for an investor when buying products or services offered by a company whose shares it owns. It is also important that in the case of benefits resulting from loyalty programs - owning shares, not disposing of them is beneficial - contrary to realizing profits from the in- 
crease in the share price. The benefits of participating in loyalty programs may even to some extent offset the losses incurred due to decrease of the share price. In addition, these benefits are realized irrespective of the economic situation on the stock exchange on continuous basis, not incidental.

The level of the share price depends not only on the company itself, but also on factors beyond the company's control. Among the elements shaped by company are the results of its operations and implemented development strategy. On the other hand, among the factors beyond the control of the company are, among others, overall economic situation as well as stock market situation, interest rates, unemployment rate and currency exchange rate. The company has no influence on these elements. That is why the loyalty program becomes even more important in this context. This is the element that company can create on its own and can manage it.

The purpose of offering loyalty programs is to encourage the investor to purchase financial instruments of the company, retain him as an investor and increase the level of his financial involvement in the company. An additional purpose of these activities is to create the company's relationship with the investor as a consumer of the issuer's products or services. In practice, this means that the company creates an integrated offer, including both its financial products offered to investors and the basic products being the company's core business, offered to consumers. The investor is potentially a natural consumer of products offered by the company whose shares it owns (scheme 3).

Author defined loyalty program as company dedicated offer for their individual investors. It aims is to increase loyalty level of individual shareholders. Loyalty for investors might be reflected in:

- holding period of shares;

- purchasing of additional shares of the same firm;

- reinvesting the dividends;

- advising other investors to buy the shares;

- lacking response to calls upon hostile takeover;

- lacking nervous reaction to crisis and one-time events.

The subject of this study are loyalty programs dedicated for investors which are alternatively know as benefits programs for investors. The research objective is to identify the need for such programs.

\section{Literature review}

The concept of loyalty programs for investors began to gain popularity in economically developed countries in the mid-1990s and is modelled on loyalty programs offered to clients. In order to participate in the loyalty program for investors, it is necessary to meet certain conditions specified by the company. It is:

- completing the declaration of joining the program;

- possession of the minimum number of shares entitling to participate in the program; 
- maintaining a minimum number of shares in the portfolio throughout the period of participation in the program.

The results of various studies confirm the importance of individual investors in managing the shareholder structure and goodwill. For example, Dennis \& Strickland (2002, pp. 1923-1949) conducted an analysis of US stock market data for the period 1988-1996 to analyse how stock prices behave on days when the stock index is falling or rising by $2 \%$ or more. They show that shares of companies held by institutional investors react much more strongly during declines than shares of companies held by individual investors. Managers of investment funds with assets exceeding USD 100 million are the quickest to withdraw their funds from a given investment. This means that if there are sharp stock price fluctuations on the market, institutional investors, and especially investment funds, are the first group of investors who either sell or buy sharply to overtake the market.

With regards to the satisfaction element which may influence an individual behaviour, Ritter (2003, pp. 429-437) posited that it is closely related to loyalty, thus the satisfied consumers presumably have high loyalty. Liu (2007, pp. 19-35) study of loyalty program for consumers shows that clients gradually purchased more and became more loyal to the firm. Through these programs, firms can potentially gain more repeat business and, at the same time, obtain rich consumer data that aid future customer relationship management efforts. Furthermore, some studies suggest that loyalty consumer programs can increase repeat-purchase numbers and share of wallet (Keh \& Lee, 2006; Leenheer et al., 2007; Sharp \& Sharp, 1997; Verhoef, 2003). Since American Airlines launched the first contemporary consumer loyalty program in 1981, loyalty programs widely expand (McCall \& Voorhees, 2010, p. 35). It is estimated that more than half of US adults are enlist in at least one loyalty program (Kivetz \& Simonson, 2002, pp. 155-170). The latest KPMG (2019, p. 45) survey recalls Nike company where members of consumers' loyalty program spend nearly triple what online shoppers do. Previous report indicates that $85 \%$ of growth comes from company's most loyal customers (KPMG, 2016, p. 4).

Meanwhile, investor loyalty is interpreted as a factor in reducing volatility and cost of capital (Gregory, 1998, p. 288).

Investor behaviour has been the subject of diverse studies in the field of behavioural finance (e.g. Shefrin, 2002, pp. 3-41; Shiller, 2003, pp. 83-104) within connection with psychological or sociological theories. While initial investment decisions are analysed, the behaviour of investors as reflected in their loyalty were relatively rarely raised. Helm (2007, pp. 22-37) found that there is no significant effect of reputation on behavioural loyalty meaning that reputation is not a forceful lever to directly influence investors' future trading intentions or the holding period of shares. In the eyes of individual investors, reputation is furthermore captured to a considerable degree by non-financial elements such as commitment to social and charitable issues. 
Schoenbachler (2004, pp. 488-497) results of the study suggest that individual investors tend to buy brands from companies in which they hold stock, and that investors may buy a stock in a company because they have had some experience with a brand managed by that company. These findings held regardless of the type of industry in which the stock was held. Such behaviours are indicative of the behavioural aspects of brand loyalty, defined in terms of repeated purchases.

\section{Methods}

The following research methods were used in the development of this article, i.e. the analysis of the literature of the subject, desk research, observations, descriptive and comparative analysis, case study and questionnaire method.

Also, a survey was conducted by the author on a sample of 306 group of individual investors on Polish capital market between December 2019-February 2020. The survey was based on questionnaire method within members of Polish Association of Individual Investors. The question analysed in the article was designed in the Likert scale form. The IBM SPSS Statistics software was used for data analysis.

\section{Results}

Based on the literature analysis of the subject and the analysis of programs offered by listed companies worldwide, some generalizations can be formulated, which is divided into two parts.

\subsection{Investor loyalty pyramid}

In the theory of economics, the concept of loyalty pyramids' developed to describe consumer attachment to a particular brand. This concept can be adopted to show the loyalty of an investor to a given company.

In the classic approach, the pyramid of loyalty reflects to what extent the consumer is willing to change the brand, especially when the company introduces a change in price or a change in the characteristics of the product or service.

In turn, the pyramid investor loyalty to the company is reflected in the extent to which the investor is willing to purchase or sell financial instruments of the company if there is a change when their prices occur with event of single market or the company itself. The layout and arrangement of such a pyramid was proposed in scheme 4 .

\subsection{Classification of loyalty programs for investors}

Loyalty programs to shareholders offered by company on the international financial market can be divided into elite and mass, taking as a criterion re- 
quired capital threshold associated with the investment and the need to freeze the funds. In the case of elite programs, they are aimed at reaching wealthier individual investors. Organized meetings with the management are aimed at integrating with this relatively small group of investors and better contact with them, and as a result personalized relations with investors and meeting the expectations of this group of owners. Mass programs are aimed at, among others, maintaining and increasing the group of small individual shareholders. Here, the aspects of shareholder loyalty and consumer loyalty are clearly combined. In this way, shareholders are encouraged to buy the products of the company whose shares they hold, in which loyalty program they participate. Therefore, broad, loyal customer base and broad, loyal investor base are built at the same time as part of the offer integrating the company's financial products and core products.

In addition, the loyalty programs offered on the market can be divided according to the type of benefits offered into: financial, non-financial and mixed.

Financial benefits include in particular:

- discounts on products offered by companies;

- option of reinvesting a dividend on favorable terms;

- additional bonus dividend depending on the duration of participation in the program.

Examples of non-financial benefits include invitations to:

- instore events such as artistic, cultural, sporting events and fashion shows;

- presentation of new products and their testing;

- dedicated meetings with the management board;

- and the opportunity to participate in the work of shareholder advisory committee which serves as both a consultative body and a forum for discussion, to improve the way to communicate with retail investors.

\subsection{Experience in offering loyalty programs}

On the international market, loyalty programs for investors are offered in many companies. Below are some of them as examples. They confirm it that in the world such programs meet with positive interest from investors. This is demonstrated by both the number of programs offered and the number of investors participating in them. For example, 700,000 investors are registered with Orange and 450,000 with L'Oréal.

Carnival Corporation (2020) which offers up to USD 250 on board credit per room in their boats trips can be mentioned as an example of a program offering discounts on products offered by the company. In Japan Airlines (2020) investors who own 100 shares can save $50 \%$ on regular one-way airfare for any domestic flight. Benefits increased with number of shares (up to 100,000 shares). In GO (2020) company benefits starts from 100 shares with products discounts from EUR 5. 
On the other hand, as examples of programs offering benefits related to participation in various cultural events, we can mention shareholders' clubs operating at French banks: Société Générale (2020) and BNP Paribas (2020) as well as Total (2020) company.

The latest trend in loyalty benefits is increase the value of dividend. Such benefit can be received from both individual and institutional investors up to certain limit. As an example of such program we can mention L'Oréal (2020) which offer $10 \%$ dividend increase for each register shares continuously hold for two full calendar years (up to a maximum of $0.5 \%$ of the capital for the same shareholder). In Albioma (2020) company loyalty bonus is provided on the same rules as in L'Oréal. Investors can also receive a larger dividend if they decide to reinvest it in new company's shares.

\subsection{Opinion of Polish investor about offering loyalty programs}

On the Polish market, several elements of loyalty programs were previously used by companies under initial public offering. The following companies can be cited as examples: Bank PKO BP, PZU (insurance), Tauron (energy), Gino Rossi (shoes) (Rudke, 2017). However, they were short-term loyalty programs.

Therefore, it can be considered that the first long-term loyalty program for individual investors was offered in Poland only in November 2018 by a company from the fuel sector PKN Orlen (2020), and then by a company from the energy sector: Energa. Advanced work is carried out in the next 6 companies.

Currently, over 3,000 individual investors are already participating in the Orlen in the portfolio beneficiary program - a pioneer who initiated these programs in Poland. To participate in the program, investor must hold 50 shares for a month. The company cooperates with 5 brokerage houses, which, among others monitor whether the minimum required number of shares remains on the investment account of the program participant. The obtained personal card confirming participation in the program entitles to obtain discounts at the company's petrol stations:

- PLN 0.1/liter for fuel and gas;

- PLN 0.15/liter for first-class fuel;

- $10 \%$ discount on other products offered at stations (excluding alcohol and cigarettes).

The total value of fuel discounts was limited to PLN 540 per year.

As part of the author's survey conducted on a group of individual investors, one of the questions asked concerned the desirability of offering such programs. The results obtained are quoted below.

Survey respondents definitely value the importance of loyalty program for investors. Merely 21 out of 305 individual investors stated that they negatively view such offer. At the same time 192 respondents positively view such offer (113 respondents choose value 5 and 79 value 4 on Likert scale). Such result can 
be perceived as proof that benefit programs are important for individual investors in Poland (chart 1).

What seemed interesting was checking if respondents declaring their support for offering loyalty programs were new or longstanding investors. Table 1 compile cross-tabulation of the two parameters. As presented, the longer the period of investing on stock exchange is the higher the increase of investors valuing importance of loyalty programs occurs.

Hence, both the results of the survey and the number of people participating in the Orlen in the portfolio program confirm that the loyalty programs receive positive assessment from individual investors in Poland.

\section{Conclusion}

Modern society and modern economy need safe and effective capital market. At the same time modern financial market and global economy development is conditioned by transparency and trust. Building and maintaining that trust is not possible without bilateral communication, especially in financial area. One of the tools to build such long-term relationships are investor loyalty programs. They are offered by many companies in the world. Currently, also in Poland, examples of the functioning of such programs can be given. This is due to the fact that these programs are positively evaluated by investors.

At the same time, it should be noted that it would be interesting to continue further studies in order to determine, whether the offering by the company's loyalty programs to investors affected somehow: the maturity of the capital market, developed standards and a culture and ethics of the operation.

\section{References}

Aaker, D.A. (1991). Managing brand equity: capitalizing on the value of brand name. New York: Free Press.

Dennis, P.J., \& Strickland, D. (2002). Who blinks in volatile markets, individuals or institutions. The Journal of Finance, 57(5). doi:10.1111/0022-1082.00484.

Dziawgo, D. (2004). Stowarzyszenia indywidualnych inwestorów i kluby inwestycyjne na rynku papierów wartościowych. Toruń: UMK.

Gregory, J.R. (1998). Does corporate reputation provide a cushion to companies facing market volatility: some supportive evidence. Corporate Reputation Review, 1(3). doi:10.1057/palgrave.crr.1540050.

Helm, S. (2007). The role of corporate reputation in determining investor satisfaction and loyalty. Corporate Reputation Review, 10(1). doi:10.1057/palgrave. crr.1550036.

Japan Airlines. (2020). Shareholder benefit program. Retrieved 02.03.2020 from https://www.jal.com. 
Kivetz, R., \& Simonson, I. (2002). Earning the right to indulge: effort as a determinant of customer preferences toward frequency program rewards. Journal of Marketing Research, 39(2). doi:10.1509/jmkr.39.2.155.19084.

KPMG. (2016). Is it time to rethink loyalty programs. Retrieved 05.03.2020 from https://home.kpmg.

KPMG. (2019). 2018 global consumer executive top of mind survey: no normal is the new normal. Retrieved 01.03.2020 from https://home.kpmg.

Liu, Y. (2007). The long-term impact of loyalty programs on consumer purchase behaviour and loyalty. Journal of Marketing, 71(4). doi:10.1509/jmkg.71.4.19.

L'Oréal. (2020). Loyalty bonus and registered shares. Retrieved 02.03.2020 from https://www.loreal-finance.com.

Ritter, J.R. (2003). Behavioural finance. Pacific-Basin Finance Journal, 11(4). doi:10.1016/S0927-538X(03)00048-9.

Rudke, M. (2017). Nieliczne programy lojalnościowe. Retrieved 02.03.2020 from https://www.parkiet.com.

Schoenbachler, D.D., Gordon, G.L., \& Aurand, T.W. (2004). Building brand loyalty through individual stockownership. Journal of Product \& Brand Management. 13(7). doi:10.1108/10610420410568426.

Shefrin, H. (2002). Beyond greed and fear: understanding behavioral finance and the psychology of investing. Oxford: Oxford University Press.

Shiller, R.J. (2003). From efficient markets theory to behavioural finance. Journal of Economic Perspectives, 17(1). doi:10.1257/089533003321164967.

Total. (2020). Le cercle: programme du cercle des actionnaires. Retrieved 02.03.2020 from https://www.total.com.

Keh, H.T., \& Lee, Y.H. (2006). Do reward programs build loyalty for services: the moderating effect of satisfaction on type and timing of rewards. Journal of Retailing, 82(2). doi:10.1016/j.jretai.2006.02.004.

Leenheer, J., van Heerde, H.J., Bijmont, H.A., \& Smidts A. (2007). Do loyalty programs really enhance behavioural loyalty: an empirical analysis accounting for self-selecting members. International Journal of Research in Marketing, 24(1). doi:10.1016/j.ijresmar.2006.10.005.

McCall, M., \& Voorhees, C. (2010). The drivers of loyalty program success. Cornell Hospitality Quarterly, 52(1). doi:10.1177/1938965509355395.

Sharp, B., \& Sharp, A. (1997). Loyalty programs and their impact on repeat purchase loyalty patterns. International Journal of Research in Marketing, 14(5). doi:10.1016/S0167-8116(97)00022-0.

Verhoef, P.C. (2003). Understanding the effect of customer relationship management efforts on customer retention and customer share development. Journal of Marketing, 67(4). doi:10.1509/jmkg.67.4.30.18685.

Carnival Corporation. (2020). Shareholder benefit. Retrieved 02.03.2020 from https://www.carnivalcorp.com.

Albioma. (2020). Our loyalty program. Retrieved 02.03.2020 from https:// www.albioma.com. 
BNP Paribas. (2020). Le cercle des actionnaires. Retrieved 02.03.2020 from https://cercle-actionnaires.bnpparibas.

GO. (2020). Investor loyalty scheme 2018-2019. Retrieved 02.03.2020 from https://www.go.com.mt.

PKN Orlen. (2020). Orlen w portfelu. Retrieved 02.03.2020 from http://orlenwportfelu.pl.

Société Générale. (2020). Mon espace actionnaire. Retrieved 02.03.2020 from https://monespaceactionnaire.societegenerale.com.

\section{Acknowledgements}

Author contributions: author has given an approval to the final version of the article.

Funding: this research was funded by the Nicolaus Copernicus University in Torun, Faculty of Economic Sciences and Management statutory sources. 


\section{Appendix}

Table 1.

Cross-tabulation for assessment of offering loyalty programs for shareholders and length of stock investing

\begin{tabular}{lcccc}
\hline $\begin{array}{c}\text { How do you rate offering } \\
\text { loyalty programs for } \\
\text { shareholders? }\end{array}$ & $\begin{array}{c}\text { up to 3 years } \\
\text { (new investors) }\end{array}$ & $\begin{array}{c}\text { Years of investment } \\
\text { (experienced investors) }\end{array}$ & $\begin{array}{c}\text { over 10 years } \\
\text { (veterans investors) }\end{array}$ & Total \\
\hline 1 - negatively & 1 & 7 & 13 & 21 \\
2 & 1 & 12 & 12 & 25 \\
3 & 7 & 33 & 27 & 67 \\
4 & 10 & 42 & 25 & 77 \\
5 - positively & 26 & 49 & 36 & 111 \\
total & 45 & 143 & 113 & 301 \\
\hline
\end{tabular}

Notes:

$\mathrm{N}=301$ (number of valid answers in individual investors sample).

Source: Own preparation.

Scheme 1.

Parties initiating encouraging of natural people to save

\begin{tabular}{|l|l|l|}
\hline government & \multicolumn{1}{|c|}{ associations of individual investors } & company \\
\hline & & \\
citizens
\end{tabular}

Source: Own preparation. 
Scheme 2.

Potential financial benefits realized by investor

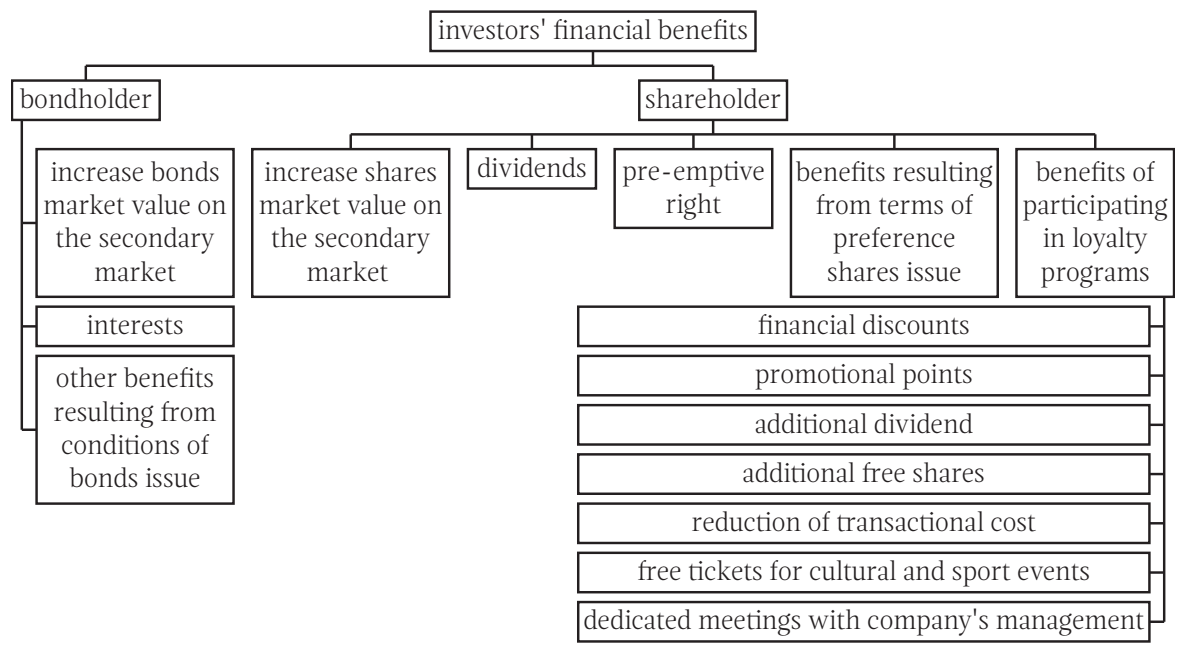

Source: Own preparation.

Scheme 3.

Integrated products offer for investors via loyalty program

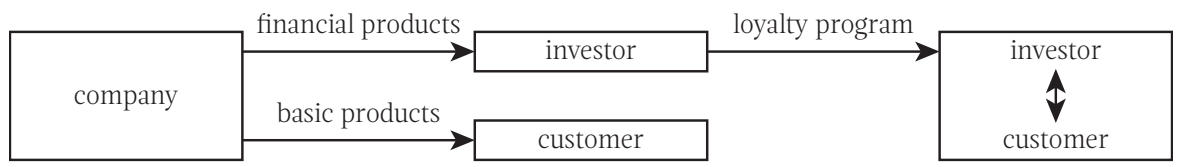

Source: Own preparation.

\section{Scheme 4.}

The loyalty of individual investors pyramid

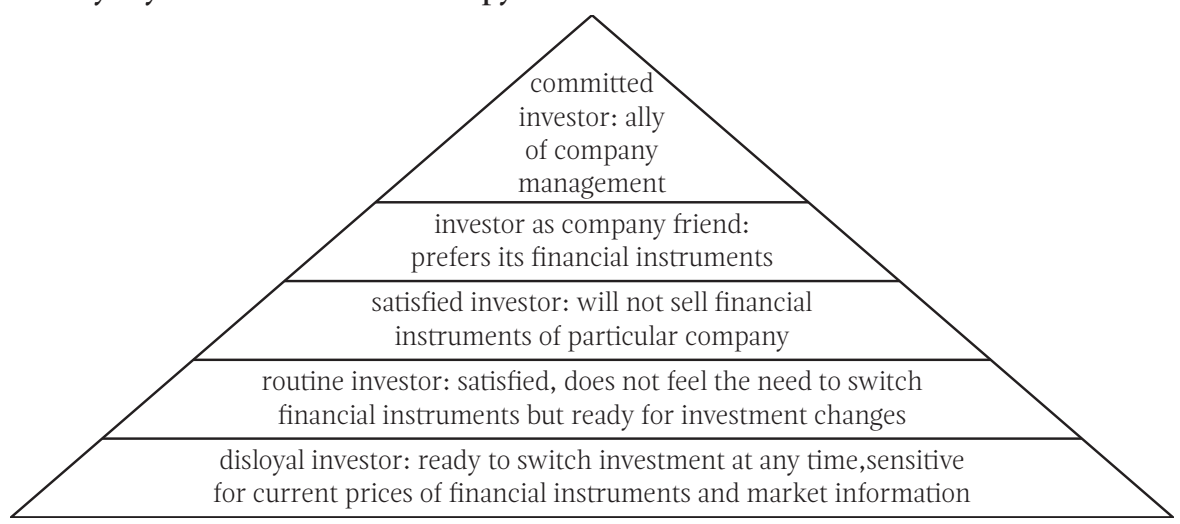

Source: Own preparation based on Aaker (1991, p. 40). 


\section{Chart 1.}

Distribution of responses to the question: How do you rate offering loyalty programs for shareholders? (in \%)

40

37.0

35

30

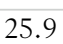

25

20

15

10

$$
6.9
$$

8.2

5

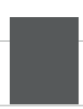

1

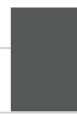

2
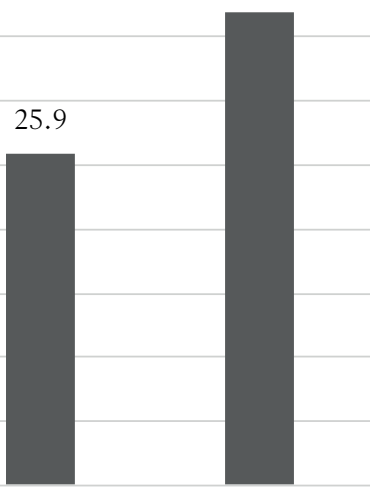

3

4

5

Notes:

$\mathrm{N}=305$ (number of valid answers in individual investors sample)

1 - negatively, 5 - positively

Source: Own preparation. 
